\title{
Women's rights in Pakistan: A study of religious and alternate discourses regarding women's participation in politics
}

\author{
Ishaq Ahmad $^{* 1-2} \mid$ Shahida Aman ${ }^{1}$
}

1. Department of Political Science, Faculty of Social Sciences, University of Peshawar, Pakistan.

2. Department of Pakistan Studies, Shaheed Benazir Bhutto University, Sheringal, Dir (U), Pakistan.

* Correspondence Emails: ishaq@ @bbu.edu.pk | ishaqahmad59@gmail.com

\begin{abstract}
This study aims to evaluate the religious and the alternate discourses on women's political rights in Pakistan; such debates were heightened and intensified as a result of General Zia-ul-Haq's Islamization vision and policies implemented between 1977 to 1988 . Zia-ul-Haq's Islamization is argued to have polarized women's participation in politics and challenged the standing of feminist groups, Islamic feminists, and secularists, which made Islam and women's political participation the subject of debates that are still relevant in the case of Pakistan. The paper argues that Pakistani state's Islamic disposition in general and Zia-ul-Haq's Islamization in particular provoked religious conservatism and promoted gender-based discrimination that deeply affected women's political participation. This study seeks to reconcile the different perspectives of Islamic and secular feminism for realizing the goals of effective participation of women in politics. The paper uses a qualitative research method concentrating on thematic analysis, which employs for identifying and analyzing patterns or themes within qualitative data analysis approaches. The findings suggest that in the case of women rights, Islamic feminism and secular feminism are compatible and complementary, and a synthesis of both is imperative to realize the effective participation of women in politics.
\end{abstract}

\author{
Article History \\ Received: \\ July 31,2020 \\ Last Revised: \\ January 13, 2021 \\ Accepted: \\ February 14, 2021 \\ Published: \\ April 21, 2021
}

Keywords: rights of women, religious discourses, secular discourses, military regime, Islamization, Islamists, gender equality, equal rights, political participation.

How to Cite: Ahmad, I., \& Aman, S. (2021). Women's rights in Pakistan: A study of religious and alternate discourses regarding women's participation in politics. Liberal Arts and Social Sciences International Journal (LASSIJ), 5(1), 123-138. https://doi.org/10.47264/idea.lassij/5.1.9

Publisher's Note: IDEA PUBLISHERS (IDEA Journals Group) stands neutral with regard to the jurisdictional claims in the published maps and the institutional affiliations.

Copyright: ( 2021 The Author(s), published by IDEA PUBLISHERS (IDEA Journals Group). This is an Open Access article published under the Creative Commons Attribution-NonCommercial 4.0 International License (http://creativecommons.org/licenses/by-nc/4.0/) 


\section{Introduction}

Women's political participation has always been a central subject of Islamic scholarship that is highly debated throughout the course of Islamic history. Women have been continuously victimized in their social-political circles and deprived of their due rights via justifications based on religious grounds. Many of the developing states that are governed by traditional and religious structures and having multi-cultural and multi-sectarian religious approaches are confronted with worsening status of women. Islam, which was the driving force in bringing unity among Muslims of the Subcontinent and creating Pakistan as an independent state for Muslims of India made a profound impact on Pakistan's political identity. The chief identity problem about Pakistan being an Islamic state or simply a state for the Muslims of the SubContinent led to the creation of different ideological positions during the early constitutionmaking process. The Ulema have since the start been advocating and attempting to realize their vision of the polity and society that have had far-reaching implications for the role of women in public life. Additionally, the traditional and patriarchal orientations on women's public role have harmed their political participation in Pakistan. However, such gender biases based on religious and cultural structures were complemented by gender discrimination policies adopted and sustained on the legal and political platform during General Zia-ul-Haq's Islamization Program between 1977 to 1988 .

The Islamization process was initiated by General Zia-ul-Haq's military regime with the support of the Ulema (Muslim scholars having knowledge of Islamic sacred law and theology) belonging to different religious school of thoughts comprising Juma'at-i-Islami (JI) and Jamiat-i-Ulema Islam (JUI), two major religio-political parties in Pakistan. It promoted institutionalized gender inequalities based on the concept of disparate social roles for each gender that expelled women from public life and thwarted their political activism. Prior to Ziaul-Haq's era, the state ideology endorsed a version of Islamic modernism that was an act of appeasement towards the political position of women. Following this, the Constitution of 1973 granted full participation of women in politics. However, this right was suddenly curbed in the Zia-ul-Haq's era.

General Zia-ul-Haq's Islamization policies polarized the process of women's participation in politics and challenged many feminist groups, comprising Islamic feminists (modernists) and secularists, who, in turn, questioned the authority and accounts of Ulema restricting women from politics. It also brought the issue of women's participation in politics in Islam to the forefront of debates, which still persists in Pakistan. Was Islamization the centre piece of Ziaul-Haq's military regime? Does religion or the interpretation of religion create barriers to women's participation in politics? Should the justification for women's participation in politics be waged from an Islamic framework or a secular framework? This paper addresses these questions and more. The central question at the core of this debate is: Can Islamic feminism and Secularism be engaged in a compatible and complementary manner to provide the framework for women's participation in politics? The paper argues that for effective women's participation in politics, both, Islamic feminist approach and a secular framework are imperative and should be continuously engaged. Since Muslim countries have generally seen low participation of women in politics due to religious and cultural reasons, therefore, the primary objective of this study is to broaden the comprehension of Muslim population and elite in such societies about religion and women's political rights. This investigation on Islam and women's political participation and their leadership role takes a more nuanced approach on how religion and gender can function productively and create an outlook for gender equality. 
Such exploration also contributes to understanding the power vested in women by Islam; in other words, to realize that it is the religion which empowers women in many respects; such efforts are needed today to reject the misrepresentation of the Western media that Muslim women are oppressed.

The debate in the paper has been divided into four main categories: Traditionalists, Fundamentalists, Modernists and Secularists. The Traditionalists and Fundamentalists, the first two groups also called Islamists, are against any public role of women. The third group, i.e., the Secularists asserts that feminism and Islam are incompatible. The fourth group that states that feminism and Islam are compatible is the Modernists, also termed as the Islamic Feminists. Besides using the Quranic injunctions, the paper also relies on the 1979 CEDAW, United Nations Convention on the Elimination of all Forms of Discrimination against Women, as a secular framework to analyze the contending debates on women's human rights.

\section{Literature review}

The contemporary anti-feminist and misogynistic attitudes and practices in Muslim societies are an outgrowth of historical processes and, therefore, not an inherent feature of Islam. Barlas (2002) while explaining traditionalism and patriarchy's incorporation in Islam argues that it is essential to know about the historical context of Quranic revelations for the purpose of understanding its teachings. However, it is quite necessary to realize the historical context of its interpretations to understand its conservative and patriarchal exegesis. A large work not only in the Quranic interpretations but also in the laws and traditions had been produced during the first few centuries of Islamic history; the classical age of Islam. It was assimilated into Islam through commentaries and super commentaries on the Quran (Tafsir) and the narratives of the life and practices of the Prophet (Ahadith) that enabled the textualization of misogyny in Islam. Thus, the blend of history, culture and widely varied religious teachings, not only distorted the more progressive image of women, but also degraded them to the status of an incompetent, weak and unfitted creature. This belief endorsed gender hierarchy on the premise that women are inferior and subordinate to men in every department of life, which in turn led to women's secondary role in the overall decision-making processes.

However, as argued by Kurzman (2002), the modernization movement, which was launched by Muslim intelligentsia in the middle of the $19^{\text {th }}$ century to cope with European domination and influences, provoked intellectual fervour all over the Islamic world. The movement looked for reconciliation of Islamic beliefs and modern standards; constitutionalism, nationalism, modern-style education, cultural resurgence, and freedom of religious interpretation. All of these had strongly influenced the Muslim world, including Egypt, Iran, Turkey, and Muslim India. Gender reforms including women's modern education and their participation in public life were one of the important themes of this movement in many Islamic regions.

In the context of British India, the subsequent rapid socio-economic and political changes led modernist Muslim elites to redefine and improve the position and role of women as part of the overall social reform. But traditionalists rejected modernism and justified gender position and role differentiation and male supremacy over women under divine mandates. Until the Freedom Movement in India, the modernist theory superseded traditionalism in all aspects that, eventually, led to the creation of Pakistan. Yet, the involvement of religion in the Movement sustained traditionalism to hold sway over the Muslims through Ulemas, who migrated to Pakistan. Therefore, a substantial part of intelligentsia, including Saigol (2016) and Yilmaz \& 
Ahmed, (2018), identify ideology as a main hurdle to Pakistan's political identity, which has negative impacts on women's rights.

Mehdi (2013) mentioned different ideological positions, including traditionalists, modernists, fundamentalists, and secularists to be involved during the early constitution-making process. Therefore, since the beginning these positions have been advocating and endeavouring to realize their vision of the Pakistani state that has had far-reaching implications for women's public roles. Ahmad (2010), and Khan and Rehman (2018) on the other hand, sees this ideological divergence on women's public rights in the context of the transformation of varied ideological leadership in different phases of nation-building process in Pakistan. For instance, according to Muhammad Ali Jinnah, the leader of the Pakistan movement, the ideal woman was one who was fully involved in national life to render services for the uplift and progress of the country. Conversely, other leaders, particularly General Zia-ul-Haq, defined the ideal role of women as good caretakers of their homes.

The same position is extolled by Weiss (2014), who asserts that though Pakistan is a signatory of the CEDAW and has brought legal reforms and policies affecting women's rights, however, divergent views on the position and role of women in Pakistan has made the overall conditions highly disadvantageous for women. Therefore, she recommends that there is a need to review the various ideological positions to build a consensus on women's rights, which she calls a prerequisite of the modern world. Employing the perspective of building a consensus on women's rights in Pakistan, particularly in the context of women's participation in politics, this study attempts to reconcile Islamic feminism with a secular framework. The above brief literature review signifies that while recognizing the lesser participation of women in politics in Muslim societies these works primarily seek its reason in the contending ideological, historical, modern, and secular debates on Islam and women's political rights. To address this important gap, my work, on the other hand, seeks to bring about synthesis in the different positions taken on women's political rights, which is the failure of the above writings. In other words, this research attempts at finding the synthesis or the complementarity of debate in the Secular and Islamic Feminists writing and, therefore, asserts that both these positions can be fused and blended to help achieve the objective of greater political participation of women in Muslim societies.

\section{Research methodology}

The paper employs a qualitative research design focusing on discourse analysis to generate findings. This is in turn attempted through a thematic analysis of the discourse, identifying and analyzing patterns or themes within qualitative data. Therefore, as a first step, the analysis concentrates on themes such as Zia-ul Haq's Islamization Program and its negative impacts on women's political participation, Islamists view on women's participation in politics, Modernists and their take on women's political rights, and Secularist position on women political and leadership roles; thereby a descriptive summary of every ideological position is given. At the second and last step, the study focuses on compatibility between Islamic feminism and the secular framework regarding women's political participation, which is sought through building a comparative perspective between them. The study is based on secondary data analysis from already published literature available in the form of articles, books, reports, and newspapers. The study then uses thematic discourse analysis to extol the socio-religious and cultural debates associated with Islamic, secular, and modern interpretations of women's political rights in Muslim societies. The discourse analysis is justified because the paper not 
only aims at analyzing thematically the discourses on women's political rights from different perspectives, but also attempts to bring out the synthesis between secular and Islamic feminist debates regarding the justifications for women political rights. Therefore, the different texts and collections in all the different perspectives were analyzed on multiple levels. Like other doctrinal and religious studies, this research does not assert to deal with the issue in its completeness; yet, it paves the way for understanding the ideological fault lines in different positions including the Islamists, Islamic Feminists and secularists on women's rights and obtaining conflation in the different perspectives of Islamic Feminism and a secular framework regarding women's political participation.

\section{The Islamists, Islamic Feminists, Secularists, and Zia's Islamization}

As Z. A. Bhutto's downfall was mainly attributed to his un-Islamic and secular behaviour, Ziaul-Haq devised his policies to legitimize and extend his military dictatorship through the instrumental usage of Islam (Burki, 2016). Accordingly, he proclaimed that since Pakistan was established for the Muslims of India; therefore, it was to be reformed according to Islamic injunctions for its transformation into a true Islamic state (Imran \& Munir, 2018). In this way, he planned to justify his military autocracy and prolong his unlawful stay in power and make his position stronger. To seek patronage for his enterprise, he managed to manoeuvre and seek support of religious groups, including Juma'at-i-Islami and Jamiat-i-Ulema Islam. Ahmad (1996) argues that the reason the Islamist parties supported General Zia's regime is that the Islamists did not have a political mandate and had considered to be suffered because of democratization. Therefore, they took an advantage of the opportunity by forging alliances with the military ruler to implement their blurred vision of Islam in the country. Zia-ul-Haq also attempted to transform Pakistan into a traditional Islamic society by invoking Islam as a universal set of laws and conduct, and presenting the West as 'the other,' an innate enemy of the Muslims. This demarcation was used as a mechanism for controlling that segment of the population, which was considered to be imitating the West, meaning the modernists, the feminists, and the secularists. In other words, this demarcation signified 'the other' within the polity and the society of Pakistan.

For the traditionalists and the Islamists of Pakistani society, the position of women is one of the major yardsticks to distinguish the Muslim civilization from the Western one. Therefore, for Zia-ul-Haq, women presented a perfect tool and symbol for conversion of Pakistan into an ideal Islamic state. The Islamists had borne growing concerns about women's public role and considering it a Western and anti-Islamic concept. Therefore, Zia-ul-Haq's government took drastic actions against women's public sector activities through a series of legislations; this was done to manipulate the Islamists' anxiety. He thwarted women's political activism by pushing them into traditional patriarchal social structures to release their anxiety caused by the so-called Westernization forces in Pakistan. The conservative brand of Islam as propagated by the regime polarized the process of women's participation in politics, which pitted feminists against Islam. The feminists challenged the Islamists' monopoly over religion and their accounts justifying women's political non-participation; there by bringing Islam and women's participation in politics to the forefront of debates in Pakistan.

\subsection{The Islamists and Zia's Islamization}

The Islamists in Pakistan are of the opinion that the Quran and Sunna (the right pathway as revealed in the sayings and practices of Prophet Muhammad) have provided comprehensive 
and concrete guidelines regarding women's rights and these rules are universal and infinite. They believe that Islam has given women the primary role and responsibility is to be good mothers. Therefore, women should not participate in public roles unless there are emergent conditions as it will threaten the very fabric of the Muslim society and its innate classification. The Islamists insist on complete segregation and asymmetric gender roles in society as they argue that Islam has distributed duties between men and women in such a way that God has assigned the public duty of political affairs to men while women have to perform the domestic duties. Public domain and running of affairs require strength, stamina and endurance, which God has given to men. And as women have less physical potency, therefore, the domestic duties, which need less bodily strength and are easy to perform, have been bestowed upon the women. They critique that the West's propaganda of women's emancipation opens the doors of politics and government for women to unshackle them from the purdah, chastity, and modesty; is nothing but to drag them towards disgrace, brazenness and immorality, a way to destroy the innate fabric of Muslim society. Islam by no means permitted women to leave their homes and deal with outdoor businesses including politics and state affairs and, conversely, to involve them in politics and decision-making processes would be a pathway towards new innovations in the premise of Islam. According to them, there is no concept of mixed society in Islamic principles. Therefore, women are not allowed to equally participate with men in all spheres of life (Usmani, 1999; Cheema, 2014).

Dr. Israr Ahmad, the ex-member of JI, was a member of the Majlis-e-Shoora (Central Advisory Council) during Zia-ul-Haq's military regime. He outlined his idea of an ideal Islamic state and claimed that as a prerequisite of a true Islamic state all women who are working in public sectors must take early retirement and should be pensioned off at once as in a true Islamic state there was no option for women to leave the boundaries of their homes and take part in outdoor activities except under compelling need (Mumtaz \& Farida, 1987). To materialize his Islamization vision and policies, General Zia-ul-Haq acclaimed and accepted such proposals and authorized the Islamists to enact laws regarding public (men's) and private (women's) spheres. The lawmakers (Islamists) focused on women's sphere by introducing Chadar (sheet of cloth using for covering head and body) and Chardivari (the four walls of the home); creating separate offices and working places for female government employees, banning foreign services jobs for women, prohibiting their participation in public sports, closing female membership of all kinds unions and ceasing almost all those ways which are a prerequisite of political gateway (Saigol, 2016).

As such, the Islamists originated the theory of gender inequality and inferred that women are inferior to men as Islam reduces their blood money (money paid, as by a killer or the killer's clan, to the family of a person who is killed) and treats their evidence (in case of a single women) as inadequate and inadmissible (Haagensen, 2018). They exploited the same stereotypes as a rule in the legal and social subordination of women and opined that the modernists are responsible for spreading the Western propaganda of women's emancipation and wrongly advocating that women and men are the equal genders and created for the same functions; thus, this dragged women into public role in the society and politics of the state. They argue that Modernists have failed to understand that men and women have different intellectual properties, physical and bodily structures, susceptibilities, mental trends and sentiments, which reflect that women are genetically inferior and determined for different functions than men (Cheema, 2014; Larsen, 2018). Therefore, they "want to overturn the status quo by dismantling Western-style institutions and ideologies... habits and customs...that lead to injustice towards women" (McNeil, 2003: 145). 
There is a general belief among the Islamists that women are physically and intellectually less capable than men in handling various public responsibilities and situations. This stems from a de-contextualized and patriarchal interpretation of a particular Quranic verse "Men are qawwamun of women, because Allah has given the one more (strength) than the other, and because they support them with their means" (4:34). This entire verse and more particularly the word 'qawwamun' are interpreted differently. Islamists translate the word 'qawwamun' as ruler, governor, manager, protector, lord, and sovereign (Hassan, 1988; Mir-Hosseini, 2018) and argue that all these terminologies are used in the jurisdiction of politics which is men's sphere. They also refer to some Ahadith as shreds of evidence regarding men's superiority to women; that God first created man and then woman. And that woman was the main cause of man's exclusion from the Garden of Eden. The woman is a by-product of man (Hassan, 1991; Barlas \& Finn, 2019). Therefore, a nation which assigns its affairs to a woman can never prosper (Osmaniet al., 2020). In a reaction, Zia-ul-Haq's regime took a concrete step by closing the office of Amir-e-Mumlakat (head of state) for women. He also placed a condition that women less than fifty years of age could not become members of the parliament and would have to produce written permission from their husbands to take part in politics and competing elections (Ansari Commission's Report, 1983). Thus, it is argued that Islamization process based on such notions predominantly deteriorated women's political participation and put them in an unequal political position.

\subsection{The Islamic feminists (modernists) and Zia's Islamization}

Islamic feminists argue that Islam, if properly understood, can be completely compatible with feminism. According to this view, the Quranic standards are alive and can be reinterpreted to make it applicable to different contemporary situations and needs. They assert that in the context of changing social, economic, and political circumstances it is the patriarchal version of Islam that has led to Muslim women's not being treated as men's equals. This inequality has grown through a historical artifact of patriarchal authorities, specifically Muslim jurists. Therefore, one of their most important functions is to challenge the belief that one can be called a Muslim only if one recognizes the Muslim jurisprudence as obligatory upon itself and those who believe in Muslim jurisprudence as divine in nature. They refute the divine nature of Muslim Jurisprudence and argue that most of the Muslims do not know that it is a man-made blend of customs and Islamic values and elevate it to the level of divine nature that causes biased gender Islamic laws, which affect women negatively and disproportionately (Shaikh, 2015; Mir-Hosseini, 2018).

Islamic feminists assert that the Quran or true Islam has no such absolute foundation, which makes it compulsory for women to wear the veil in public places. And that the Quran dictates simply that when men and women come together, they drop gazing each other and focus on hiding their private parts. Women are further directed to cover their chests and do not expose their jewellery. Therefore, the Quran advocates sexual modesty instead of veil or segregation of sexes. The prime objective of Islam after women's dress and behaviour is to allow them to carry out public activates at no cost of harassment and molestation (Asadi \& Hooshangi, 2018; Barlas \& Finn, 2019). They also assert that the joint Islamization program of General Zia-ul Haq and Islamists had no grand objective than to reduce Muslim women's status to less than full humanity. They used religion against women's oppression rather than liberation and offered traditional theological interpretations that spread negative ideas and attitudes about women's status and role in society. These theologians or religious hierarchies obliged women to allow the myths which they used to chain up their bodies, souls, and minds. Such coercion 
and repression were employed to strengthen cultural identity and kept women inside the four walls (Hassan, 1991).

Contrary to the perception of gender hierarchy, Modernists opine that the concept of gender disparity is a trap into which Islamists have fallen. The leading patriarchal authorities, Islamists, have offered a number of Islamic interpretations to make women inferior creatures. They employ some disputed Ahadith tending to limit the scope and teaching of the Quran, which Muslims believe as a sacred book and divine guidelines. They are committed to the literal and de-contextualized interpretations of the Quranic verses disregarding the fact that the Quran frequently delivers symbolic speeches to reveal profound insights. They also do not understand the chief ethical standards of the Quran which declare that both men and women are deputies of God on earth. The Quranic perspective thus reveals that men and women have the same status and position in society. Therefore, Islamic feminists reject using religion against women's oppression and permit them to realize their human potentials in all spheres of life (Hassan, 2011).

Islamic feminists remark that Islam does not prohibit women from public roles and puts an end to traditional constraints on their actions and choices. In contemporary Muslim societies, there is a need of Ijtihad (rational ruling) to know about the essence of the Quran and to make it applicable to the particular contemporary situations and circumstances. Despite other issues, a central argument to this message is: to wipe out all types of inequalities and discriminations and to establish a just social order on earth. They point out that one of the fundamental rights of women, which the Quran puts emphasis on, is the right to seek knowledge (Quran, 96: 1, 96: 4, \& 96: 5). Similarly, Islam permits women to work, enjoy independent earnings, and retain property rights (Quran, 62: 10, 4: 32, \& 4: 7). These rights are not the monopolies of men only. On the contrary, in Pakistan the seeds of traditional and patriarchal theological views, which had been sown by the Islamists during Zia-u-Haq's military regime are still advocating negative perceptions about women's public sector roles. As stressed by some scholars, until we pull down the foundations of traditional theological beliefs which have developed misogynistic and androcentric attitudes, Muslim women will suffer discrimination in politics (Hassan, 1991; Behzad, 2017).

The term 'qawwamun,' the Modernists argue has been interpreted out of context to expel Muslim women from the sphere of politics. They opine that 'qawwamun' is wrongly interpreted as ruler, governor, lord, master, and manager. This reflects the traditionalists' intentions of making men rulers and managers of political affairs by driving out women from politics and establishing a political hierarchy in Muslim society. The word qawwamun does not signify ruler-ship. It carries an economic meaning of 'breadwinner.' The verse deals with this responsibility of men in marital life. It says that in married life, a woman becomes free from the responsibility of earning bread as this responsibility falls upon a man. But it does not signify that women/wives are or cannot be breadwinners as the verse directs men in the context of married life and tells them about one of their responsibilities and does not stop a woman/wife from earning. However, the traditional interpretations have changed the essence of the verse which affects women's equality and brings them under the virtual control of men (Hassan, 1986; Barlas \& Finn, 2019). They also look at the Ahadith that are used by the Islamists to establish women's social inequality with men and shape the classical and patriarchal interpretation of the Quran and claim that the theology about women folk implied in the Ahadith is at odds with the spirit of the Quran. Therefore, these Ahadith ought to be vetoed based on their content (Hassan, 1991; Barlas \& Finn, 2019; Stack, 2020). 


\subsection{The Secularists and Zia's Islamization}

The secular feminists state that Islam and feminism are incompatible and perceive the women's suffering in Pakistan as a part of the larger general suffering of women under the patriarchal social structures. They explore women's rights outside the parameters of Islamic law and put an emphasis on the equality of gender and the dismantling of all patriarchal institutions and ideologies. They say that the issue of women's rights is an issue of the human rights discourse and hold the state responsible for using Islamic rhetoric and the prevailing patriarchal supremacy (McNeil, 2003).

The secularists reject and challenge all particularities of the veil and the four walls concept during Zia-ul-Haq's Islamization, which according to them were no more than placing women within the home as an object of pleasure for their spouses, proclaiming them irrational, incapable, and dependent on men, and assigning them disparate legal and social statuses and roles (Imran \& Munir, 2018). They opine that this notion was popularized through Islamists, who were delivering sermons in mosques and emphasizing the character of the Iranian Islamic model as a best one for shaping women's position in Pakistan, and supplemented by statecontrolled media (Rouse, 1986; Sheikh \& Ahmed, 2020). Thus, women were the lynchpin of Zia-ul-Haq's Islamization Program. He undertook to maintain the sanctity of Chadar and Chardivari by taking over women's lives, controlling their movements, bodies, and space primarily through a determined ideology that women are subordinate to men and that they ought to be controlled.

The Women's Action Forum (WAF) is a secular organization which emerged in the 1980s against General Zia-ul-Haq's Islamization program and remained active throughout his period. The WAF, including their female lawyers and other members, met with a tough resistance and condemned limitations of the Islamization program comprising the most objected and controversial recommendations of Ansari Commission that affected the political status of women (Weiss, 1985; Imran \& Munir, 2018). This commission was appointed by General Ziaul-Haq's government on July 10th, 1983, with the purpose to submit proposals regarding the system of government in Islam, which imposed strict conditions on women's political participation. It was chaired by Zafar Ahmad Ansari, a Muslim scholar; therefore, it is called Ansari Commission. To level the equality of women with men and to achieve social, economic and political rights, the WAF's members and activists, including Asma Jhangir, Hina Jilani and Bushra Ahsan appealed to the International Human Rights Commission and demanded that Pakistan should be a secular state. They considered themselves to be part of the International Women's movement. Bushra Ahsan argued that WAF's efforts should be focused more to the international community than to Pakistan's society (McNeil, 2003).

This group succeeded in raising a strong voice for women's rights in Pakistan. They pressed for permanent constitutional security of gender equality, non-discrimination based on gender roles, strived for women's rights in line with international agreements and the UN Declaration of Human Rights, and emphasized that the main reason of women's plight is their barring from joining decision-making processes. They submitted women's question to the national and international agenda, offered a tough resistance to discriminatory legislation, endeavoured best for women's rights and launched a campaign for Pakistan to become a member of United Nations Convention on the Elimination of all Forms of Discrimination against Women. However, Pakistan being a party of CEDAW, which is a forum to empower women's rights, still supports the authority of patriarchal ideologies, Islamists (McNeil, 2003). 


\section{The compatibility between Islamic feminism and secular framework}

In the preceding religious discourse, four different ideological positions of women's rights, particularly women's participation in politics, were discussed: the approach of traditionalists and fundamentalists, also called the Islamists' approach; the Islamic feminist approach and the secular approach. In the above discourse, we argued that Islamist's standpoint is patriarchal and conservative about women's participation in politics, which conflicts with the secular framework. This stance of Islamists creates a position for us to move towards the Islamic feminism and secular framework and construct a comparative perspective to find out whether compatibility exists between them. The compatibility between Islamic feminism and secular framework regarding women's political participation is surrounded by three main areas: i) gender equality in Islam, ii) Purdah; fixed customary women's roles, reproduction, and household chores, and iii) women's participation in politics and appointment at high levels in governmental structure, which are the scope of this study.

This compatibility is very crucial for the effective participation of women in politics. Pakistan is a classical Islamic and patriarchal society where, due to strong conservative religious culture, women lack adequate opportunities and resources to participate in politics and become state actors. This is evident from the different phases of Pakistan's political history that show a marginal representation of women in political and legislative forums, which led to the construction of the discriminatory laws by the legislative forums having had a majority of males encompassing conservative religious elites. Conversely, women's higher number in the formal political forums, in turn, affect their position positively either through fighting for modifying the old biased gender laws or enacting new feminist legislation, which is the immediate requirement of modern democratic societies. Thus, women's full participation in politics brings an emancipating message to them to express their concerns and to realize their full human rights.

\subsection{Gender equality}

Article 1 of the United Nations Convention on the Elimination of all Forms of Discrimination Against Women (hereinafter, Convention) guarantees gender equality and defines discrimination, which encompasses any difference based on gender affecting women's human rights and fundamental freedoms. It ensures equality of women in all public spheres' activities including politics (Burrows, 1985). Islam promotes gender equality as the Quran says, "O Mankind! Be conscious of your sustainer, who created you from a single person (nafsinwahida), and created its mate of like nature, and form the two spread abroad a multitude of men and women" (Ali, 1999).

Islamic feminists argue that the Quran in the context of the creation of human beings adopts complete egalitarian approach. The Quran in more than thirty occasions, while dealing with the creation of humanity in multiple ways, never asserts or suggests about gender superiority or inferiority. They point out that the belief that men are superior to women, which has been affecting women's lives profoundly, has its origin in the patriarchal exegesis of the mentioned passage (4:1) in which classical commentators attribute the term nafs to Adam. It leads to the traditional theological assumption that God's primary creation is Adam---male and that Hawwa (Eve) ---female, not ever mentioned in the Quran, had been created from Adam's rib. Hence, the woman, being a by-product of man, is inferior and subordinate to man. They go into the rigorous hermeneutical scrutiny of the afore-mentioned passage and infer that the term 
"Adam," which is a Hebrew term, means "the soil," functions generally as a collective noun and refers to the human (species) rather than to a particular human being, Adam. It is also imperative to note that in the Quran the term Adam, in twenty-one cases out of twenty-five, refers to humankind. This denotes that the term Adam usually does not signify a particular human being; it does stand for human beings in a particular way. Therefore, they believe in the single origin and the same rights of all humankind (Hassan, 1991).

Accordingly, all men and women are equal before Allah (SWT). Everyone is responsible for their actions. No one shall be held responsible for other's doings (Quran, 74: 38). They are independent (Quran, 4: 32) and are granted grades based on their doings and that God may confer rewards on them against their deeds and no injustice be done to them (Quran, 46: 19). Islam specifies only one criterion for superiority of one over the other and that is righteousness (Quran, 49: 13). For that reason, an individual who is more God-fearing, a paragon of virtue, is superior to other. Hence, an un-virtuous man is not qualified for the superiority against a virtuous woman who meets the criterion. Thus, in the context of gender equality in Islam, there is no difference between a man and a woman.

Based on this natural identicalness, Islamic feminists assert that Islam gives humankind guarantees of all fundamental rights. These human rights are innate and profoundly form our human character. Their ban or defiance is to be equivalent to the denial of those basic standards which make us beings. Subsequently, Islam gives the right to life, which is sacred and declines illegal permission to take life. It gives everyone the right to education and places emphasis on receiving of knowledge. As such, it allows the same opportunities for employment for both men and women and makes them independent for investing their earnings. Islam treats man and woman equally. It permits both woman and man to pursue all legal professions. Enjoy their earnings, retain property rights, and follow any legal process. A woman might pursue any legal career. She has the right to keep her earnings, inherit property and discard her belongings at will. This concept of equality ensures for her the right to participate in politics and hold political office (Hassan, 2011; Chowdury, 2018).

\subsection{Purdah, fixed customary women's roles, reproduction, and household chores}

The Convention (Article 5) acknowledges that, to realize the de-facto equality for women in the economic, social, and political sectors, there is a need for fundamental changes in sociocultural patterns. These patterns are based on the traditional beliefs which outline fixed customary women's roles in society; reproduction and household chores (Burrows, 1985). Hassan (2011) argues that the traditional and conservative concept of veil and segregation is nothing more than adopting the pre-Islamic traditions and oppressing women's public roles. The belief that women must have the veil and segregation, as women's entrance in male space disrupts the natural order of society, is a twisted form of a Quranic idea. The main objective of the Quran regarding women's dress and conduct is to enable women to carry out public activates free from molestation and harassment. Patriarchal authorities, however, do not concentrate on the real context. To confine women in their home and to veil them in the name of so-called 'women's chastity' at the cost of their free will and ability to perform public sphere activities is a distortion of the Quranic directives and the adaptation of discriminatory beliefs about women based on the traditional and patriarchal interpretation of Quran.

Islamic feminists remark that there are no explicit instructions in the Quran regarding the veil for women. The verses that address the issue of women's attire and educate them for securing 
their private parts and covering their bosoms with a scarf are 24: 31-32. Besides, all other related verses, particularly 33: 59 and 33: 53 deal with the veil or seclusion of the Prophet's wives, therefore, the Quranic verses regarding seclusion or veiling for the women are context related. They refer to the verse 33: 59 and argue that this verse enjoined the veiling when some hypocrites tended to ridicule the Prophet's wives as they mistook them for slaves. Regarding the verse 33: 53, they opine that the background of this revelation is based on a series of accounts encompassing Muhammad's (PBUH) wedding with Zeinab binti Jahsh when a small number of guests stayed on too long in Zeinab's room that annoyed Mohammad, touching of the hands of Mohammad's (PBUH) wives with some men guests at this or some other meal occasion, and asking the wives of the Prophet (PBUH) by someone. Besides the aforementioned accounts, Modernists assert that the term veil or seclusion merely refers to the seclusion of the Prophet's (PBUH) wives and the commandments pertaining to their veiling or covering their bodies. They conclude that veiling is a cultural custom, which existed in Arabian and most chiefly among Assyrian, Roman, Greek, Jewish and Indian societies and was associated with an elevated social status. It assimilated into the corpus of Islam and ordinary Muslim women's life when Muslims conquered these territories, where veiling, as a fixed morally binding custom, was already prevailed (Ahmad, 1992; Syed, 2004; Grech, 2016). In Pakistan, such blend of socio-cultural norms and conservative conceptions in the garb of religion have pre-dominated traditional religious groups that, under the pretext of purdah, relegate women to home for the task of reproducing and undertaking household chores and obstructing their participation in politics.

\subsection{Women's appointment at high level governmental structures}

Article 7 of the Convention endorses women's right to vote in all elections and public referendum; their effective participation in the formulation of government policy; and the right to be elected to public office (Shah, 2006). Similarly, Islam also acknowledges women's public role. The Quran describes that "establishment of authority in this world is a kindness of Allah towards the whole community: ... who (conduct) their affairs by mutual consultation ... and consult them (women) in affairs (administration)" (Shah, 2006: 48). Thus, the mentioned verses denote that both men and women have the right to participate in state's affairs and take part in the course of decision-making.

The Islamic feminists assert that a comprehensive study of the Quranic rulings reveal that there is no restriction on women's political participation in Islam. They have the right to vote and hold any public office including office of the head of the state. They opine that most of the Muslim scholars are not in favour of women's political participation and leadership roles, even though the Quran implies no such terms that signify that leadership and politics is not the jurisdiction of women. They argue that this is the legacy of the ancient Arabian patriarchal culture, where only males had the privilege to operate in the public sphere, which is still lived that tends to disadvantage women. However, the Quran neither mentions such drawbacks of women nor any ruling indicates that politics and leadership are the jurisdictions of men only. Conversely, in the context of patriarchal Arabian culture, the Quran illustrates the example of a female ruler, Bilqis, the queen of Sheba, extremely well and is given favourable consideration. The Quran mentions her characteristics of wisdom and self-determination as a leader and head of the state and elaborates both her political and religious practices. In the Quran, excluding identifying her as a woman, no limitation, restriction, distinction or specification regarding her personality and governance are ever mentioned. Thus, the general standard for leadership in the Quran is corresponding to the principle of functional 
specialization; that a function should be done by one who is suited for it, which implies that the Quran does not thwart females from holding authority, either over females or together over women and men (Wadud, 1999; Muhibbu-din, 2019).

Challenging the androcentric and misogynistic accounts of Islamists, Modernists argue that Islamic history portrays that women during the Prophet's (PBUH) time had been released from slavery and violence to claim their right as equal citizens and participate in the building processes of Arabia. All women of Medina, under the political leadership of the Prophet (PBUH), were granted full citizenship, the status of Sahabiyat (glorious and dignified Muslim women of the Prophet's (PBUH) period who devoted themselves to propagation of Islam and accomplishing the varied socio-political and educational missions). They, including Prophet's (PBUH) wives, had the right to attend the councils of the ummah (the Muslim community), speak freely to their leader---the Prophet (PBUH), fight for their rights, and take part in the military and political affairs. There are shreds of evidence in Islamic history and the biographical accounts of the Sahabiyat that they constructed Muslim society side by side with their male counterparts (Mernissi, 1991; Muhibbu-din, 2019). Mernissi (1991) concludes that any man who considers that a Muslim woman who wants to be treated with respect and has the right of citizenship eliminates herself inevitably from the Muslim community and is a staunch advocate of western civilization is a man who does not know about his religious legacy and cultural identity. It is therefore that if we go through the history of the Muslim society objectively, we will recognize that Muslim women have the right to fully participate in the affairs of the modern world. We would also identify that their motive for social equality, human rights and extensive participation in socio-political affairs and democratic processes stems from no Western values, but is an integral component of the Muslim tradition.

\section{Conclusion}

Religion played a key role in the creation of Pakistan and in the making of consecutive constitutions and policies. However, it has always been exploited for political objectives. Any government, which looked for popular support stressed the role of religion in the system and life of public. As Military regimes had overthrown the popular governments, therefore, they seriously needed to do this to stay in the power. To achieve their objective, they had to win the support of religious factions. Conversely, religio-political parties, which had no political hegemony, forged alliance with military regimes to achieve their political ends and their dogma became an important piece of legislation; Zia-ul-Haq's military regime is a case in point. The nexus between Islamists and Zia-ul-Haq's military regime had fulfilled their ambitions but seriously damaged women's human rights.

It has been observed in the foregoing religious discourse that the Islamic feminism argues about Islam as not only advocating gender equality, but also giving women equal status and rights in all areas of life, including politics and statecraft. And that some of the rulings of the Quran and some Ahadith related to women's social milieu are interpreted and commentated in a decontextualized form, which are expressly discriminatory towards women. The argument asserts that when these decrees of the Quran and Ahadith are interpreted and commentated in their proper contexts, it becomes clear that Islam never discriminates based on gender. The comparison between the Islamic and human rights standards regarding women's political participation suggests that the rules and spirit of Islam and the human rights approach are compatible. In Islam, women and men are bestowed almost with similar rights to work and retain property, along with civil and political rights. In the same way, the UN Convention's 
principles advocates non-discrimination, equality of gender and women's participation in all public spheres and politics and demolition of all patriarchal and cultural traits. The Islamists' conservative approach, which does not acknowledge the international human rights, is untenable since the Islamic standards in the area of women's political participation match with the international human rights values and principles. Therefore, if the Quranic verses, which are related to the women's public roles, are reinterpreted in their appropriate context, greater compatibility with human rights especially for women may be realized. The view, hence asserts that the Islamic feminism and the secular framework are compatible and complementary, and in Pakistan, both are imperative to realize the effective participation of women in politics. It further promises to shift the focus of study on Pakistan away from violence and terrorism to democracy, human/gender rights and good governance, which are pre-requisites for improving Pakistan's international image and standing.

\section{References}

Ahmad, M. (1996). The crescent and the sword: Islam, the military and political legitimacy in Pakistan, 1977-1985. The Middle East Journal 50(3), 372-386. http://www.jstor.org/stable/4328957

Ahmad, S. (2010). The multiple locations and competing narratives of Pakistani women. In: Ahmad, S., \& Khan, A. (Eds.) Pakistani women: Multiple locations and competing narratives. Oxford University.

Ahmed, L. (1992) Women and gender in Islam: Historical roots of a modern debate. Yale University.

Ali, A. Y. (1999). The meaning of the Holy Quran. Maryland.

Ansari, M. Z. (1983). Ansari commission's report on form of government. Islamabad: Ministry of Education.

Asadi, S. \& Hooshangi, T. (2018). A theological approach to the identity challenges of a modern Muslim woman. Journal of Islamic Studies, 6(1), 1-10. https://doi.org/10.15640/jisc.v6n1a1

Barlas, A. (2002). Believing women in Islam: Unreading patriarchal interpretations of the Qur'an. University of Texas.

Barlas, A. \& Finn, D. R. (2019). Believing women in Islam: A brief introduction. University of Texas.

Behzad, W. (2017). A spell to empower women: Religion, culture, and domestic violence in Pakistan. New Voices in Asian Research, 2(1), 1-10. https://yorkspace.library.yorku.ca/xmlui/bitstream/handle/10315/34159/YCAR_NV $\underline{\mathrm{A} 0201 . \mathrm{pdf}}$

Burki, S. K. (2016). The politics of misogyny: General Zia-ul-Haq's Islamization of Pakistan's legal system. Contemporary Justice Review, 19(1), 103-119. https://doi.org/10.1080/10282580.2015.1101683

Burrows, N. (1985). The 1979 convention on the elimination of all forms of discrimination of women. Netherlands International Law Review,32(3), 419-460. http://journals.cambridge.org/NLR

Cheema, S. A. (2014). The concept of Qawama: A study of interpretive tensions. Hawwa, 11(23), 235-251. https://doi.org/10.1163/15692086-12341245

Chowdury, S. R. H. (2018). Empowerment of women in Muslim communities, a practical observation: A case study on the Republic of Turkey. In: Ullah, R. \& Hasan, S. (Eds.). Contemporary world: Policy, politics and international relations. Iksad Publishing. 
Grech, M. (2016). Islam and the veil: Theoretical and regional contexts, edited by Theodore Gabriel and Rabiha Hannan. Bloomsbury, 2011. 224pp., Hb. \$136.00, ISBN-13: 9781441187352; Pb. \$39.95., ISBN-13: 9781441135193. Implicit Religion, 19(3), 472-480. https://doi.org/10.1558/imre.v19i3.32495

Haagensen, L. (2018). Women, Islam and the state in Pakistan. Senior Capstone Projects. https://digitalwindow.vassar.edu/senior_capstone/759.

Hassan, R. (1991). Muslim women and post-patriarchal Islam. In: Cooey, P. M., Eakin, W. R., \& McDaniel, J. B. (Ed.). After Patriarchy: Feminist transformations of the World Religions. (pp. 39-69), Orbis Books, Maryknoll. http://riffathassan.info/wpcontent/uploads/2014/03/Muslim_Women_and_Post_Patriarchal.pdf

Hassan, R. (2011). Members, one of another: Gender equality and justice in Islam. http://www.religiousconsultation.org/hassan.htm.

Hassan, R. (1991). The issue of woman-man equality in the Islamic tradition. In: Grob, L., Hassan, R., \& Gordon, H. (ed.). Women's and men's liberation: Testimonies of spirit. Greenwood.

Imran, R., \& Munir, I. (2018). Defying marginalization-Emergence of women's organizations and the resistance movement in Pakistan: A Historical Overview. Journal of International Women's 132-156. https://vc.bridgew.edu/cgi/viewcontent.cgi ?article=2063\&context=jiws.

Khan, N. U. \& Rehman, A. U. (2018). National Character and Leadership in Pakistan: Challenges and Response. Pakistan Journal of Criminology, 10(2), 57-71. http://www.pjcriminology.com/wp-content/uploads/2019/01/4.pdf

Kurzman, C. (Ed.). (2002). Modernist Islam, 1840-1940: A sourcebook. Oxford University.

Larsen, L. (2018). How muftis think: Islamic legal thought and Muslim women in Western Europe. Brill.

McNeil, K. (2003). Towards a de-polarization of the Pakistani women's movement. In Charles H. K. (ed.). Pakistan at the millennium. Oxford University.

Mehdi, R. (2013). The Islamization of the law in Pakistan (RLE Politics of Islam). Routledge. https://doi.org/10.4324/9780203381298

Mernissi, F. (1991). Women and Islam: An historical and theological enquiry. Basil Blackwell.

Mir-Hosseini, Z. (2018). Women's equality. In Sajoo, A. (Eds). The Shari'a: History, ethics and law. I. B. Tauris.

Mistead, B. (1988). Feminist theology and women in the Muslim world: An interview with Riffat Hassan. Feminist Theology. http://wrrc.wluml.org/sites/wluml.org/files/import/english/pubs/rtf/dossiers/dossier4 ID4-02-riffat-hassan.rtf

Muhibbu-din, M. O. (2019). Feminism and modern Islamic politics: The fact and the fallacy. International Journal of Islamic Thought, 15, 44-59. https://doi.org/10.24035/ijit.15.2019.005

Mumtaz, K., and Farida, S. (1987). Women of Pakistan: Two steps forward, one step back. Vanguard Books.

Osmani, N. M., Farooq, M. O., \& Ahmad. (2020). Women empowerment and leadership in Islam between myth and reality (Chapter-3). In: Azid, T., \& Ward-Batts, J. L. (Eds.) Economic empowerment of women in the Islamic world: Theory and practice. World Scientific.

Rouse, S. (1986). Women's movement in Pakistan: State, class, gender. South Asia Bulletin, 6(1), 
http://wrrc.wluml.org/sites/wluml.org/files/import/english/pubs/pdf/dossier3/D3-06Pakistan.pdf

Saigol, R. (2016). Feminism and the women's movement in Pakistan: Actors, debates and strategies (Country Study). Friedrich-Ebert-Stiftung FES-Pakistan. https://library.fes.de/pdf-files/bueros/pakistan/12453.pdf.

Shah, N. A. (2006). Women, the Quran and international human rights law: The experience of Pakistan. Brill.

Shaikh, S. (2015). Islamic law, Sufism and gender: Rethinking the terms of the debate. In: MirHosseini, Z., Al-Sharmani, M., \& Rumminger, J. (Eds.) Men in charge: Rethinking authority in Muslim legal tradition. Oneworld Publications.

Sheikh, M. Z. H., \& Ahmed, Z. S. (2020). Military, authoritarianism and Islam: A comparative analysis of Bangladesh and Pakistan. Politics and Religion, 13(2), 333-360. https://doi.org/10.1017/S1755048319000440

Stack, R. (2020). An analysis of Muslim women's rights based on the works of Amina Wadud, Fatima Mernissi, and Riffat Hassan. Doctoral dissertation, Harvard University. https://nrs.harvard.edu/urn-3:hul.instrepos:37365037

Syed, M. A. (2004). The position of women in Islam: A progressive view. State University of New York.

Usmani, M. T. (1999). Discourses on Islamic way of life. Darul-Isha.

Wadud, A. (1999). Qur'an and woman: Rereading the sacred text from a woman's perspective. Oxford University.

Weiss, A. M. (1985). Women's position in Pakistan: Socio-cultural effects of Islamization. Asian Survey, 25(8), 863-880. https://doi.org/10.2307/2644115

Weiss, A. M. (2014). Interpreting Islam, modernity, and women's rights in Pakistan. Springer.

Yilmaz, I., \& Ahmed, Z. S. (2018). Islam and women rights in Pakistan. SSRN. https://ssrn.com/abstract $=3229025$ 